Институт за български език „Проф. Л. Андрейчин“ при БАН, София

krasimirkoilov@abv.bg

\title{
ВЛИЯНИЕ НА СЪВРЕМЕННИТЕ ДЕМОГРАФСКИ ПРОЦЕСИ ВЪРХУ ТОПОНИМИЯТА В ПЛОВДИВСКИЯ РЕГИОН*
}

Кл юч о в и д д м и: Пловдивски регион, демография, топоними, теренно проучване

Демографските промени в Република България са много динамични през последните 25 години и оказват влияния върху различни области на живота. Миграцията променя облика на населените места, а това би следвало да има отражение и върху топонимията, набора от използвани местни названия. Проучването на топонимията с оглед на връзката й със социодемографските процеси е новаторски подход, който дава възможност да се представи актуалното състояние на системата от местни имена, да се разкрие динамиката в топонимното развитие и да се анализира начинът, по който имената функционират в общността. Основната цел е да се ексцерпират актуални данни, въз основа на които ще бъдат направени изводи за това как демографските процеси формират топонимията във втората по големина област в България. В теоретичен план социологически ориентираното проучване дава възможност да се анализира как езикът и нематериалната култура като цяло следват динамиката в социалното развитие.

Неблагоприятните тенденции в демографското развитие в България през последните десетилетия са сред най-актуалните теми за науката и обществото днес. Безспорно и езикът ни е засегнат от тези, определяни от мнозина като катастрофални, демографски процеси. Намаляването на населението е основната причина за изчезването на езиците (ЮНЕСКО 2003; Джоунс 2013), но и други демографски фактори оказват влияние върху състоянието на езика и отделни негови подсистеми. В тази връзка географските названия (топонимите) като част от устната традиция са застрашени в не по-малка степен. Ето защо анализът на взаимовръзката между топонимията и демографията в синхронен аспект е особено актуален, тьй като ще покаже до каква степен българската топонимия е засегната от неблагоприятните демографски тенденции и как те предопределят развитието й днес.

* Настоящото изследване е финансирано по програма на Българската академия на науките за подпомагане на млади учени. N: 189. 
Българската топонимия е социален конструкт, който се създава, съществува и развива в рамките на обществото и обслужва ежедневната комуникация. В този смисъл тя е зависима от социокултурната динамика и отразява много точно всички езикови, демографски, икономически и политически промени. Фактически това се осъществява чрез появата или отмирането на названия, както и чрез промяна в начина на назоваване на обектите от околната среда. И тъй като през последните десетилетия демографските процеси в българското общество са много интензивни в следствие смяната на политическата система и на глобализационните процеси, това означава, че и топонимията също се променя, следвайки неговото развитие. Тези процеси трябва да бъдат изследвани на място, на микроравнище, чрез теренни проучвания, защото това е единственият сигурен начин да се установи актуалното състояние на топонимията днес.

Топонимията като интердисциплинарна наука, чиято цел е проучването на имената на географските обекти в лингвистичен план, т.е. изясняване на техните езикови характеристики, на произхода и значението им, има дълга традиция в България (вж. Георгиев, Заимов, Дуриданов, Ковачев, Чолева-Димитрова и др.). Към момента топонимното богатство у нас в значителна степен е проучено на макроравнище, т.е. названията на големите общоизвестни географски обекти са събрани и описани, изяснен е (доколкото е възможно) техният произход и значение. Голямата мисия на българската топонимна наука - събирането в цялост на всички местни имена (селищни, водни, теренни и др.) на територията на българското езиково землище - за съжаление все още не е осъществена, което поставя България сред малкото страни в Европа, които не са изучили в пълнота своето ономастично наследство. За съжаление до този момент топонимията на Пловдивския регион, един от най-обширните административни райони, не е изследвана системно и в цялост. Изключение представляват някои краеведски проучвания, посветени на определени населени места и конкретни топоними, както и някои капитални трудове по българска ономастика (Младенов 1918; Заимов 1967, 1973, 2012; Янакиева 2009). В последно време, от края на 20 в., науката за географските имена пое нова посока, следвайки развитието на социалните и хуманитарните науки. В тази връзка тя все повече разчита на теоретични постановки и методи, заимствани от тъкмо тези науки. Ето защо изследването на топонимията в синхрония с помощта на комплекс от количествни и качествени методи се превръща в особено актуална задача (Löfström, Schnabel-Le Corre (eds.) 2015; Tent 2015). Всичко това представлява добра отправна точка за предложения тук нов модел за синхронно изследване на местните имена, при който акцентът пада върху демографското развитие като основен фактор за съвременната динамика на топонимната система в Пловдивския регион.

Основната цел на проучването е да се съберат актуални топонимни данни чрез провеждане на поредица от теренни проучвания от неизследвания до 
момента Пловдивски регион, за да се представи достоверна картина какви са реално използваните от населението местни названия. В теоретичен план изследването цели да предложи един не толкова традиционен, за подобен тип топонимни проучвания, а по-скоро иновативен и съобразен с актуалните тенденции, анализ на емпиричните данни с оглед на протичащите в региона демографски промени. Подобна интерпретация е в съзвучие със съвременните схващания за необходимостта от проучване на социалните аспекти на топонимията. В тази връзка изследването си поставя следните задачи:

1. Да се установи дали реално употребяваните топоними са регистрирани (напр. в административни документи) и съществуват ли нефиксирани до момента названия и какъв е техният процент.

2. Да се анализира какви са новите названия (според вида на топонимите и според езиковите им характеристики), ако се открият такива.

3. Да се определи как обезлюдяването и миграцията влияят върху количеството на използваните топоними.

4. Да се проследи доколко количеството на използваните топоними зависи от възрастовите характеристики на населението на дадено селище, т.е. дали „младите” селища боравят с по-богат топонимен инвентар или напротив.

5. Да се анализира доколко количеството и видът на използваните топоними зависи от промените в бита и производството, напр. как промяната в предназначението на земята рефлектира върху топонимната номинация.

6. Да се изследва влиянието на глобализацията и урбанизацията върху количеството и вида на използваните топоними, напр. какво е отражението на регионалния и/или глобалния пазар и развитието на инфраструктуратавърху количеството и вида на местните имена.

Основният принос от провеждането на емпиричното проучване е, че ще бъде установено с точност какво е актуалното състояние на топонимията в Пловдивския регион днес, в условията на динамични демографски процеси. Другите не по-малко важни резултати са:

1. Предлага се нов модел за синхронно изследване на топонимията у нас, при който демографското развитие в даден регион се разглежда като основен фактор за съвременната динамика на топонимната система.

2. Ексцерпиране на надеждни количествени данни, които ще бъдат анализирани с оглед на демографската ситуация в региона. По този начин ще се направят изводи затова как демографските процеси формират топонимията във втората по големина област в България. Тези обобщения, от своя страна, могат да бъдат екстраполирани и спрямо други региони в страната.

3. Регистриране на нови, неизвестни досега за изследователите названия, както и нови принципи на номинация, които ще покажат доколко устойчива е топонимията като изразител на нашата културна идентичност в глобализиращия се свят. 
4. Изводите и обобщенията от теоретичните анализи ще бъдат от полза за широк кръг хора както в академичните среди, така и извън тях, които се интересуват какво е въздействието на демографските процеси върху една, на пръв поглед не толкова позната, но много важна за националната ни идентичност, сфера на българската култура.

За ексцерпиране на емпиричен материал, както и за извличане на актуални данни относно демографското състояние на включените в проучването селища се използват качествени методи като нестандартизирано интервю и дълбочинно интервю. Според оценката на методолозите в исторически план дълбочинното интервю е първият социологически изследователски метод, който излиза от традиционната рамка на количествените методи и поставя началото на нова категория методи за набиране на емпиричната информация. Най-общо дълбочинното интервю се определя като специфичен вид интервю, провеждано под формата на свободен разговор с изследваното лице (Ченгелова 2016: 63). То се използва за изследването на нови или сравнително малко изучени обекти, процеси и явления. Целта му е да събере информация, обогатяваща предварително съществуващите представи или водеща до създаването на такива (ако явлението е съвсем ново и неизучено). В този смисъл дълбочинното интервю има сондиращ, експертен характер и се провежда на първоначален план, като подготовка за количествено, предварително изследване.

Преди осъществяване на теренното проучване бяха изработени критерии за класифициране на населените места от североизточната част на Пловдивския регион, според които селищата бяха разделени в четири групи: 1) селища, намиращи се в близост до голям пътно-транспортен възел и/или индустриална зона (Радиново, Костиево, Бенковски, Царацово, Стряма и Цалапица); 2) селища, намиращи се в близост до културни и туристически центрове (Старосел, Калояново, Паничери, Дуванлии); 3) селища, характеризиращи се с наличие на различно вероизповедание (Шишманци, Болярци); селища, намиращи се в силно обезлюдени и изоставащи райони (Бабек, Чоба и Тюркмен).

През първия етап на проучването бяха изследвани 12 селища и бяха събрана актуална информация, показваща тяхното реално демографско и топонимно състояние.

Теренната работа в село Радиново (община Марица) установи увеличаване на населението на селището поради преврьщането му в едно от шестте средища, където се развива проект „Тракия индустриална зона“, осигуряващо постоянни и стабилни доходи. Липсват пустеещи къщи, а точно обратното има ново строителство и засилена урбанизация на селото. Рядко се регистрират миграционни процеси извън рамките на селото на млади или по-възрастни лица. През последните години движението на хората е насочено към пределите на населеното място, където те се заселват. Доминира българският етнос (97\%), а ромският е слабо застьпен (3\%). Не се откриват представители на други етни- 
чески групи. Населението на 100\% изповядва източно православно християнство. От изследваните 52 (ексцерпирани от различни източници) топонима 83\% все още имат жива употреба сред населението. Останалите 17\% са посочени от информаторите като непознати. Въпреки разрастващото се урбанизиране на населеното място, местните названия са запазили своя изконен произход и автентичен изговор в непроменен вид. В речта и в традициите на именуване не са навлезли комерсиални названия - неоними (нови имена). В село Радиново се срещат топоними като: Азките, Косов мост, Потока, Средна пара, Трапът, Юртовете и т.н.

Проучването в село Костиево (община Марица) доказа умерено увеличаване на населението на селото, защото то е едно от шестте средища, където се простира проект „Тракия индустриална зона“, даващо постоянни и стабилни доходи. Откриват се малък брой пустеещи къщи. Слабо регистрирани миграционни процеси извън рамките на селото на млади или по-възрастни лица. Доминира българският етнос (90\%), а ромският е умерено застъпен $(10 \%)$. Не се откриват представители на други етнически групи. Населението изповядва източно православно християнство (от целия български етнос и част от ромския) и мюсюлманство. От изследваните 356 (ексцерпирани от различни източници) топонима 55\% още имат жива употреба сред населението. Останалите $45 \%$ са посочени от информаторите като непознати. Въпреки разрастващото се урбанизиране на населеното място, местните названия са запазили своя изконен произход и автентичен изговор в непроменен вид. В речта и в традициите на именуване не са навлезли комерсиални названия неоними (нови имена). В село Костиево се срещат топоними като: Армана, Барата, Бряста, Бъзите, Динкоджа, Уиите и т.н.

Изследването в село Царацово (община Марица) показа увеличаване на населението на населеното място, тъй като то е част от ареала, където се развива проект „Тракия индустриална зона““, позволяващо да има постоянни и стабилни доходи. Има незначителен брой пустеещи къщи, а точно обратното - има ново строителство и засилена урбанизация на селото. Рядко се регистрират миграционни процеси извън рамките на селото на млади или по-възрастни лица. През последните години движението на хората е насочено към пределите на населеното място, където те се заселват. Доминира българският етнос (99,9\%), а ромският е слабо застьпен $(0,1 \%)$. Не се откриват представители на други етнически групи. Населението на 100\% изповядва източно православно християнство. От изследваните 145 (ексцерпирани от различни източници) топонима $86 \%$ все още имат жива употреба сред населението. Останалите $14 \%$ са посочени от информаторите като непознати. Въпреки разрастващото се урбанизиране на населеното място, местните названия са запазили своя изконен произход и автентичен изговор в непроменен вид. В речта и в традициите на именуване са навлезли мальк брой нови названия - неоними (нови имена) - 
Дулаптарла и Малката вада. Тук се откриват и топоними като: Айгъна, Вадите, Гълъбица, Джеби гьол, Мъртвицата, Пумпалища и т.н.

Проведеното на терен проучване в село Стряма (община Раковски) обобщи увеличаване на населението на селището. То също е едно от шестте средища, където се развива проекта „Тракия индустриална зона“, имащо предпоставки за постоянни и стабилни доходи. Липсват пустеещи къщи, а точно обратното има ново строителство и засилена урбанизация на селото. Рядко се регистрират миграционни процеси извън рамките на селото на млади или по-възрастни лица. През последните години движението на хората е насочено към пределите на населеното място, където те се заселват. Доминира българският етнос (90\%), а ромският $(9 \%)$ и турският $(1 \%)$ са слабо застъпени. Населението изповядва източно православно християнство и мюсюлманство. От изследваните 337 (ексцерпирани от различни източници) топонима $15 \%$ все още имат жива употреба сред населението. Останалите $85 \%$ са посочени от информаторите като непознати. Въпреки разрастващото се урбанизиране на населеното място, местните названия са запазили своя изконен произход и автентичен изговор в непроменен вид. В речта и традициите на именуване не са навлезли комерсиални названия неоними (нови имена). В землището на село Стряма се откриват топоними като: Азмака, Аржсовиа, Бахчите, Долна поляна, Камъните, Карагирен и т.н.

Изследването на село Цалапица (община Родопи) маркира намаляване на населението на селото поради миграционни процеси извън населеното място на предимно млади членове на обществото, защото трудно се осигурява постоянен и стабилен източник на доходи. Отчита се малък брой пустеещи къщи. Рядко се регистрират миграционни процеси към рамките на селото на млади или по-възрастни лица. Доминира българският етнос (91\%), а ромският е слабо застъпен (9\%). Не се откриват представители на други етнически групи. Населението на $100 \%$ изповядва източно православно християнство. От изследваните 75 (ексцерпирани от различни източници) топоним $84 \%$ все още имат жива употреба сред населението. Останалите $16 \%$ са посочени от информаторите като непознати. Въпреки разрастващото се урбанизиране на населеното място, местните названия са запазили своя изконен произход и автентичен изговор в непроменен вид. В речта и в традициите на именуване не са навлезли нови названия - неоними (нови имена). Тук се откриват топоними като: Алевища, Бобевииа, Гърбища, Каракашица, Лъката, Чернота и т.н.

Интервютата на терен в село Бенковски (община Марица) посочиха увеличаване на населението на селището, защото то е част от проект „Тракия индустриална зона“, предпоставка за постоянни и стабилни доходи. Регистрират се малко на брой пустеещи къщи, а точно обратното - има ново строителство и засилена урбанизация на селото. Рядко се регистрират миграционни процеси извън рамките на селото на млади или по-възрастни лица. През последните години движението на хората е насочено към пределите на населеното мяс- 
то (предимно млади семейства), където те се заселват. Доминира българският етнос (96\%), а ромският $(3,5 \%)$ и арменският $(0,5 \%)$ са слабо застьпени. Населението изповядва източно православно християнство и мюсюлманство. От изследваните 221 (ексцерпирани от различни източници) топонима 20\% все още имат жива употреба сред населението. Останалите $80 \%$ са посочени от информаторите като непознати. Въпреки разрастващото се урбанизиране на населеното място, местните названия са запазили своя изконен произход и автентичен изговор в непроменен вид. В речта и в традициите на именуване не са навлезли комерсиални названия - неоними (нови имена). Тук се откриват топоними като: Бозалъка, Гамовица, Горен герен, Калчов бряст, Миневи ливади, Съдината и т.н.

Проучванията в град Съединение (община Съединение) установиха сравнително стабилно намаляване на населението на града поради естествени, биологични причини и миграция на лица към други населени места заради липсата на стабилен източник на доходи. Откриват се пустеещи къщи. Рядко се регистрират миграционни процеси към рамките на населеното място. Доминира българският етнос (90\%), а ромският е умерено застъпен (10\%). Не се откриват представители на други етнически групи. Населението на $100 \%$ изповядва източно православно християнство. От изследваните 110 (ексцерпирани от различни източници) топонима 97\% все още имат жива употреба сред населението. Останалите $3 \%$ са посочени от информаторите като непознати. Въпреки демографските процеси (застаряване на населението и миграция към други населени места в България и извън нея), протичащи в населеното място, местните названия са запазили своя изконен произход и автентичен изговор в непроменен вид. В речта и в традициите на именуване не са навлезли нови названия - неоними (нови имена). В град Съединение се откриват топоними като: Алова черницуа, Белизмата, Буфкача, Зад Зайкови, Папуча, Росенките и т.н.

В село Чоба (община Брезово) се достигна до извода за намаляване на населението на селото поради естествени, биологични причини и миграция на лица към други населени места заради липсата на стабилен източник на доходи. Откриват се голям брой пустеещи къщи. Слабо регистрирани миграционни процеси към рамките на селото на млади или по-възрастни лица. Доминира българският етнос $(70 \%)$, а ромският е силно застыпен (30\%). Не се откриват представители на други етнически групи. Населението изповядва на 100\% източно православно християнство. От изследваните 93 (ексцерпирани от различни източници) топонима 75\% все още имат жива употреба сред населението. Останалите $25 \%$ са посочени от информаторите като непознати. Въпреки демографските процеси (застаряване на населението и миграция към други населени места в България и извън нея), протичащи в населеното място, местните названия са запазили своя изконен произход и автентичен изговор в непроменен вид. В речта и в традиции- 
те на именуване са навлезли няколко нови названия - неоними (нови имена) Лозар могила и Мазъл. В село Чоба се откриват и топоними като: Герен дере, Друма, Орманя, Пясъка, Реката, Червенащите и т.н.

Село Тюркмен (община Брезово) е със силно намаляващо населението, защото са налице естествени, биологични причини и миграция на хора към други населени места заради липсата на стабилен източник на доходи. Силно застрашено от обезлюдяване населено място. Откриват се голям брой пустеещи къщи. Не се регистрират миграционни процеси към рамките на селото на млади или по-възрастни лица. През последните години движението на хората е насочено извън пределите на населеното място. Доминира българският етнос $(97 \%)$, а ромският е слабо застьпен (3\%). Не се откриват представители на други етнически групи. Населението изповядва източно православно християнство и мюсюлманство. От изследваните 51 (ексцерпирани от различни източници) топонима 99\% все още имат жива употреба сред населението. Останалите $1 \%$ са посочени от информаторите като непознати. Въпреки демографските процеси (застаряване на населението и миграция към други населени места в България и извън нея), протичащи в населеното място, местните названия са запазили своя изконен произход и автентичен изговор в непроменен вид. В речта и в традициите на именуване не са навлезли нови названия - неоними (нови имена). Тук се срещат топоними като: Брешкова нива, Дългъна, Младата градина, Попова кория, Текендере, Табаня и т.н.

Калояново (община Калояново) е село с увеличаващо се население. Незначителен брой пустеещи къщи, а точно обратното - има ново строителство и засилена урбанизация на селото. Рядко се регистрират миграционни процеси извън рамките на селото на млади или по-възрастни лица. През последните години движението на хората е насочено към пределите на населеното място, където те се заселват. Доминира българският етнос (93\%), а ромският е слабо застьпен (7\%). Населението изповядва източно православно християнство, католицизъм (1/2 от населението на селото) и мюсюлманство. От изследваните 51 (ексцерпирани от различни източници) топонима 100\% все още имат жива употреба сред населението. Въпреки разрастващото се урбанизиране на населеното място, местните названия са запазили своя изконен произход и автентичен изговор в непроменен вид. В речта и в традициите на именуване не са навлезли нови названия - неоними (нови имена). Тук се срещат топоними като: Баку, Графалийско, Донку, Дюнлюка, Каратикен, Узун кър и т.н.

В село Дуванлии (община Калояново) теренната работа показа известно равновесие в населението на селото през последните години - почти изравнени показатели на раждаемост и смъртност, на миграционните процеси от и към населеното място. Отчита се малък брой пустеещи къщи. Доминира българският етнос (86\%), а ромският е умерено застъпен $(14 \%)$. Не се откриват представители на други етнически групи. Населението изповядва източно пра- 
вославно християнство (само няколко семейства), католицизъм (в мнозинство) и мюсюлманство (от представителите на ромския малцинствен елемент). От изследваните 27 (ексцерпирани от различни източници) топонима 100\% все още имат жива употреба сред населението. Местните названия са запазили своя изконен произход и автентичен изговор в непроменен вид. В речта и в традициите на именуване не са навлезли нови названия - неоними (нови имена). В село Дуванлии се срещат топоними като: Башова могила, Билми, Казлача, Търнака, Четалюка, Язлата и т.н.

Село Бабек (община Брезово) е едно от селищата в Пловдивски регион, в което има силно намаляване на населението на селото поради естествени, биологични причини и миграция на лица към други населени места заради липсата на стабилен източник на доходи. Силно застрашено от обезлюдяване населено място. Регистрират се огромен брой пустеещи къщи. Липсват миграционни процеси към рамките на селото на млади или по-възрастни лица. Селото се състои само от представители на българския етнос. Населението на 100\% изповядва източно православно християнство. От изследвани са 52 (ексцерпирани от различни източници) топонима $80 \%$ все още имат жива употреба сред населението. Останалите $20 \%$ са посочени от информаторите като непознати. Въпреки демографските процеси (застаряване на населението и миграция към други населени места в България и извън нея), протичащи в населеното място, местните названия са запазили своя изконен произход и автентичен изговор в непроменен вид. В речта и в традициите на именуване са навлезли няколко нови названия - неоними (нови имена) - Св. Никола, Пенкови кладенции и Рай дере. Тук се откриват и топоними като: Дъмгата, Исака, Каманите, Светеца, Текията, Ханчетата и т.н.

От направения дотук обзор могат да бъдат изведени следните изводи:

1. Приблизително 99,9\% от проучените и реално употребявани от местното население топоними са фиксирани, а останалите $0,1 \%$ са не регистрирани в административните документи.

2. Новите названия, които се откриват, продължават традицията при именуването в българското землище на частните поземлени имоти. Основно това са местни названия, маркиращи водоснабдителен обект в съответната местност Малката вода, Пенкови кладенц̧и, Рай дере; оними, свързани с некрополи, гробища и култови обекти - Лозар могила, Св. Никола и т.н.

3. Въпреки обезлюдяването (селата Бабек, Тюркмаен и Чоба) процентът на използваните местни топоними е сравнително висок, което показва значението им за културно-историческата памет на жителите на тези населени места, съхраняващи своите традиции, обичаи и нрави. При процесът на миграция към селищата се наблюдава по-голям спад в броя на използваните микротопоними, показващо все по-рязкото откъсване на хората от земята и обвързването им с вътрешно селищното пространство. 
4. Селищата, в които протичат по-ускорени процеси на урбанизация, мигрират млади хора към тях, разполагат с по-богат, записан в административните документи, топонимен инвентар, но процентът на реално използваните местни названия е силно занижен. При селищата, които се характеризират със затихващи функции, по-богати на културно-исторически потенциал, процентът на реално използваните топоними от местното население е сравнително висок. В тях населението се отличава с по-висок праг на възрастта, в случая, спомагащо за съхраняването на значителна част от местните топоними.

5. Въпреки че почти всички от изследваните селища в североизточния край на Пловдивски регион са засегнати от глобализационни и урбанизационни процеси, топонимите в тях запазват своя автентичен вид и не се откриват неоними (нови имена), които да свидетелстват за промени в традициите за именуване и навлизането на „комерсиални“ названия. Системата на топонимите се оказва консервативна и запазва в почти непроменена форма своя облик през годините, въпреки измененията в бита, производството и нравите на хората.

\section{БИБЛИОГРАФИЯ}

Джоунс М. 2013: Застрашени езици и езиково многообразие в Европейския съюз, http://www.europarl. europa.eu/RegData/etudes/note/join/2013/495851/IPOL-CULT_NT(2013)495851(SUM01)_BG.pdf (достьп: 02.02.2016).

Заимов Й. 1973: Български географски имена с -јь: Принос към славянския ономастичен атлас, БАН, София.

Заимов Й. 1976: Заселване на българските славяни на Балканския полуостров: Проучване на жителските имена в българската топонимия, БАН, София.

Заимов Й. 2012: Български водопис: Географско описание, строеж и произход на имената, т. 1, 2, Фабер, Велико Търново.

Младенов С. 1918: Имената на още десет български реки, Държ. Печ, София.

Ченгелова Е. 2016: Интервюто в социалните науки, Издателство Омда, София.

Чолева-Димитрова А. 1990: Модели на топонимичното изследване на околии у нас (постижения, проблеми, перспективи), „Състояние и проблеми на българската ономастика” I, с. 40-44.

ЮНЕСКО 2003: Конвенция за опазване на нематериалното културно наследство, http://www. unesco.org/culture/ich/doc/src/00009-BG-PDF.pdf (дата на достьп: 02.02.2016).

Янакиева С. 2009: Тракийската хидронимия, Акад. изд. Проф. Марин Дринов, София 2009.

Löfström J., Schnabel-Le Corre B. (eds.) 2015: Challenges in Synchronic Toponymy, Narr Francke Attempto Verl., Tübingen.

Tent J. 2015: Approaches to Research in Toponymy, „Names” 63, No. 2, pp. 65-74. 


\section{IMPACT OF CONTEMPORARY DEMOGRAPHIC PROCESSES ON THE TOPONYMY IN PLOVDIV REGION}

\section{SUMMARY}

The Plovdiv region has been dynamically developing over the last 25 years in both economical and demographic aspect. The current demographic situation in the area reflects globalization and urbanization processes taking place in this region. Migration to and from settlements, reorganization of land property and land use, as well as other demographic factors determine the use of place names and the toponymic changes (including "birth" and "death" of toponyms). This study examines how current demographic processes affect the toponymy of the Plovdiv region. In other words, it aims at revealing the real toponymic situation in the area by conducting series of fieldwork investigations and by applying qualitative methods in data collection and analysis.

Keyw ord s: Plovdiv region, demography, toponyms, field study 